NBER WORKING PAPER SERIES

\title{
IS THERE A ROLE FOR DISCRETIONARY FISCAL POLICY?
}

\author{
Alan J. Auerbach \\ Working Paper 9306 \\ http://www.nber.org/papers/w9306
NATIONAL BUREAU OF ECONOMIC RESEARCH
1050 Massachusetts Avenue
Cambridge, MA 02138
October 2002

This paper was presented at a conference sponsored by the Federal Reserve Bank of Kansas City on Rethinking Stabilization Policy, held in Jackson Hole, WY, August 29-31, 2002. I am grateful to my discussants, Martin Feldstein and Fumio Hayashi, other conference participants, and Darrel Cohen for comments on an earlier draft, to Kristy Piccinini for research assistance, and to the Robert D. Burch Center for Tax Policy and Public Finance for financial support. The views expressed herein are those of the authors and not necessarily those of the National Bureau of Economic Research.

(C) 2002 by Alan J. Auerbach. All rights reserved. Short sections of text, not to exceed two paragraphs, may be quoted without explicit permission provided that full credit, including (C) notice, is given to the source. 
Is There a Role for Discretionary Fiscal Policy

Alan J. Auerbach

NBER Working Paper No. 9306

October 2002

JEL No. E62, H62

\title{
ABSTRACT
}

This paper reviews the state of discretionary fiscal policy. Among its findings are:

(1) In recent years, U.S. discretionary fiscal policy appears to have become more active in response to both cyclical conditions and a simple measure of budget balance.

(2) Considerable uncertainty remains about how large an impact discretionary fiscal policy has on output.

(3) There is little evidence that discretionary fiscal policy has played an important stabilization role during recent decades.

(4) Budgetary pressure may weaken the efficacy of expansionary fiscal policy. Conversely, contractionary fiscal policy might have a salutary effect on output. This possibility may be relevant for understanding the impact of fiscal policy in the 1990s, although the mechanism is unclear.

(5) The automatic stabilizers embedded in the fiscal system have experienced little net change since the 1960s and have contributed to cushioning cyclical fluctuations. But the tax system has many attributes that weaken its potential role as an automatic stabilizer, particularly with respect to investment.

(6) The government's reported fiscal position, to which fiscal policy appears responsive, represents a very poor measure of underlying fiscal balance.

\author{
Alan J. Auerbach \\ Department of Economics \\ 549 Evans Hall, \#3880 \\ University of California, Berkeley \\ Berkeley, CA 94720-3880 \\ and NBER \\ auerbach@econ.berkeley.edu
}




\section{Introduction}

On March 9, 2002, President Bush signed the Job Creation and Worker Assistance Act. The Act included a temporary increase in depreciation allowances for business spending on equipment and software, in the form of 30 percent partial expensing, and a temporary extension of unemployment benefits. At the time, the motivation of the Act was that it would provide fiscal stimulus that could help the economy recover from the first recession in a decade. Yet, whether the economy was still officially in recession at the time was not known, because the NBER dating of the recession trough had not yet occurred. Indeed, there was a clear possibility that the recession might be over. On February 28, the Bureau of Economic Analysis had released "preliminary" estimates showing that real GDP had grown at an annual rate of 1.4 percent in the fourth quarter of 2001 , following a real decline of 1.3 percent in the third quarter, a decline substantially associated with the economic disruptions caused by the September 11 attacks. This preliminary estimate updated the "advance" estimate of 0.2 percent fourth quarter growth released January $30^{1}$.

The difficulty of practicing countercyclical fiscal policy has been a staple of macroeconomics textbooks for decades. With the typical postwar recession lasting less than a year and discretionary fiscal changes subject to information, political and economic lags, knowledgeable policy makers have understood the daunting task they faced. But the strong support for this most recent "stimulus package" reminds us that policy makers may go where economists fear to tread. No politician wishes to be cast in the title role of It's the Economy, Stupid.

\footnotetext{
${ }^{1}$ The fourth-quarter 2001 growth rate was again revised upward, to 1.7 percent, when its "final" estimate was released on March 28. A month later, an advance first-quarter 2002 growth estimate of 5.8 percent was issued. As of this writing, both of these numbers have already been revised again.
} 
Even as the practice of countercyclical fiscal policy has survived, the period since the golden days of "fine tuning" has provided further caveats about its use, dating from Lucas' celebrated critique in the 1970s, emphasizing that activist policy must take account of its effects on the expectations of firms and households, to the more recent argument that tax cuts may fail to be expansionary in circumstances of budgetary duress. With the recent recession and legislative action, it is a good time to review the state of discretionary fiscal policy, considering the extent of its use, its successes and failures, and the extent to which alternative policies have been or might be available. Rather than attempting a comprehensive survey, I consider several of the issues that have arisen recently in consideration of the efficacy of fiscal policy.

\section{How Active Has U.S. Fiscal Policy Been in Recent Decades?}

In embarking on a study of U.S. discretionary fiscal policy, it makes sense to ask how active policy has been, and whether the degree of activism has changed over the years. While these are simple and straightforward questions, their answers are not. One cannot simply look at quarterly or annual changes in federal taxes and spending.

\section{Cyclical Adjustment}

The most obvious problem with looking at fluctuations in tax revenues, spending, or their difference - the budget surplus - is that each of these aggregates — especially tax revenues — is sensitive to the economic cycle. Changes occur without any active policy decisions. Indeed, as discussed further below, these changes may serve as automatic stabilizers, but they need to be left aside in attempting to measure active policy changes.

The Congressional Budget Office (CBO) computes a cyclically adjusted, quarterly measure of the federal budget surplus, based on the National Income and Product Account 
(NIPA) seasonally adjusted quarterly surplus measure. ${ }^{2}$ This "full-employment" surplus series, available from the first quarter of 1956, provides a measure of how policy has changed at the quarterly frequency; it is helpful to examine fiscal behavior at this frequency in studying countercyclical policy, given that the period of the typical recession is less than one year. ${ }^{3}$

Table 1 presents regressions relating the change in the full-employment budget surplus to the lagged measure of the full-employment GDP gap, with both measures divided by the level of full-employment GDP. The first column presents the simple regression relating these two variables over the full sample period. The negative coefficient indicates that the fullemployment surplus has fallen in response to a rise in the GDP gap, consistent with the use of discretionary countercyclical fiscal policy. The relationship, however, is weak and not statistically significant. But there are, of course, other determinants of fiscal policy. As many authors have emphasized ${ }^{4}$, U.S. fiscal policy over the years has had the property that increased levels of national debt lead to higher subsequent budget surpluses. In first differences, this implies that a higher deficit in the past should cause a tightening of policy—an increase in the current surplus. Adding the lagged budget surplus to the regression, in the second column of Table 1, confirms this prediction. The higher is the lagged budget surplus, the larger is the fall in the current full-employment surplus. This relationship is statistically significant; so too, now, is the effect of the lagged output gap.

Has the responsiveness of policy to the cycle and to the degree of fiscal balance changed over time? The final three columns of Table 1 address this question by repeating the estimation

\footnotetext{
${ }^{2}$ In addition, there is an adjustment that removes the NIPA effect of the allied contributions for Operation Desert Storm. I am grateful to Frank Russek of CBO for making these unpublished data available and explaining their construction.

${ }^{3}$ The NIPA measure of the budget deficit differs from that actually used in the Federal budget, but there is no quarterly measure of the latter available.

${ }^{4}$ See, for example, Bohn (1998).
} 
of column 2 for three subsamples. Column 5 covers the period since the second quarter of 1993, roughly corresponding to the beginning of the Clinton Administration. Column 4 covers a period of equal length immediately preceding this, and column 3 covers the balance of the sample period, through the second quarter of 1984. For this initial period, the relationship is comparable to that of the full period shown in column 2. For the subperiod extending from 1984 to 1993, though, the estimates indicate that policy was more responsive both to the cycle and to the prior budget surplus. The sensitivity to the surplus, in particular, shows a marked increase during this period that followed the large Reagan tax cuts phased in beginning in 1981 that, along with the contemporaneous defense build-up and other factors, led to a sharp expansion in national debt and deficits relative to GDP. During the final period, covering the Clinton years and the beginning of the current Bush administration, the influence of the budget surplus and, especially, the output gap, increases again. The coefficient on the output gap predicts that the full-employment surplus falls by over a third of the previous quarter's output gap.

To put this last coefficient estimate in context, consider the implied effect of an increase of one percentage point in the unemployment rate. Based on the recent Okun's law relationship, this implies a roughly 2 percent drop in output relative to its full-employment level. The coefficient of -.358 on the output gap implies a corresponding rise in the full-employment deficit of -.72 percent in the next quarter-about $\$ 75$ billion on an annual basis at the current level of GDP.

In summary, based on the estimates in Table 1, U.S. fiscal policy, as measured by changes in the full-employment deficit, appears to have been responsive to both cyclical and budgetary conditions, with the sensitivity to each factor increasing over time. 


\section{Timing and Measurement of Response}

Even purged of automatic cyclical changes in revenues and spending, there are a number of reasons why the current full-employment deficit may not offer an ideal measure of the state of fiscal policy. First, there may be changes occurring over time that have nothing to do with policy actions. For example, increasing dispersion of the income distribution, as occurred during the 1980 s and 1990s, led to increased tax revenues through the progressivity of the individual income tax. To the extent that such changes occur smoothly over time, they will be picked up by the constant in Table 1's regression model, but their patterns may be more complex than this. ${ }^{5}$

Second, a change in the full-employment surplus, even if resulting from a policy change, is not necessarily due to a contemporaneous policy change. Several major pieces of tax legislation in recent decades have included phase-in provisions that confound interpretation of changes in the full-employment deficit. Consider the sequence of events in the early 1980 s. After the massive tax cut embodied in the Economic Recovery Tax Act of 1981, there were smaller but still significant tax increases passed in the years immediately following. The net impact, though, was still a phased reduction in taxes. As the 1981 legislation included tax cut provisions that took effect as late as 1985 (when bracket indexation became effective), the net changes during the early ' 80 s might have appeared expansionary even as restrictive legislation was being passed. A similar situation exists now, as a result of the 2001 passage of the Economic Growth and Tax Relief Reconciliation Act (EGTRRA). That legislation's provisions are scheduled to be phased in over a ten-year period. Should these future changes occur during periods of recession, they might appear to reflect the use of countercyclical discretionary policy even though they were enacted long before such conditions existed or were even contemplated.

\footnotetext{
${ }^{5}$ Allowing for nonlinear changes over time, through the addition of a time trend, generally increases the coefficients in Table 1, but does not change the picture of sharply increasing sensitivity over time.
} 
Finally, as has long been noted, changes in particular components of the surplus-most obviously, changes in spending as opposed to changes in revenues - should have different effects on aggregate demand. Thus, the change in the deficit, even cyclically adjusted, is inadequate to convey the magnitude of stimulus to aggregate demand. For all three of these reasons - noncyclical autonomous changes, timing, and composition, an alternative measure of fiscal policy, based on explicit policy changes, may be preferred. For this purpose, one may construct a series using the periodic fiscal updates published by the CBO.

For many years, $\mathrm{CBO}$ has provided frequent updates of its baseline revenue and expenditure forecasts for the federal budget, covering the current fiscal year and several future fiscal years. With each update, it allocates changes in forecast revenues and expenditures to legislative or policy actions, on the one hand, and economic factors on the other (which it breaks down further into "economic" - macroeconomic — and "technical" sources, such as those associated with shifts in the income distribution). CBO typically publishes two major revisions incorporating updated economic forecasts during each year, the Economic and Budget Outlook in late January or early February, and the Economic and Budget Outlook Update during the summer. By accumulating changes between each of these forecasts (including intermediate revisions, such as those typically made in response to the release of the President's budget), one may derive a roughly semiannual series of forecast changes in revenues and expenditures. In the past, I have used the resulting series to evaluate CBO's forecasting record, focusing primarily on the revisions not related to policy (Auerbach 1994, 1999), but also focusing, as here, on the determinants of policy, albeit at an annual frequency (Auerbach 2000).

Data from CBO forecast revisions are available since summer, 1984, as the pattern of semiannual forecasts begins with the winter, 1984 Budget Outlook. For each observation, I 
measure the policy change with respect revenues, expenditures ${ }^{6}$, or their difference- - the surplus - as the discounted sum of policy changes adopted during the interval for the current and subsequent five fiscal years (relative to each year's corresponding measure of potential GDP), with the six weights normalized to sum to $1^{7}$. Based on a simple goodness-of-fit measure (the regression's $\bar{R}^{2}$ ) in a search over different values, I choose a discount factor of .5, meaning that each succeeding fiscal year's policy change is accorded half the weight of the previous one. ${ }^{8}$ To facilitate comparison with the results in Table 1, I relate these fiscal policy changes to lagged values of the full-employment GDP gap from the prior quarter, and the previous fiscal year surplus. ${ }^{9}$ Table 2 presents the results of these regressions, for the three dependent variables, for the full sample period and the first and second halves of the sample period, which approximately correspond to the last two subperiods examined in Table 1.

The results in Table 2 are generally consistent with those in Table 1. Over the full sample period, both the GDP gap and the budget surplus exert a significant, negative impact on surplus-enhancing policy actions, with both revenues and outlays responding in a consistent manner. The strength and precision of the effects are smaller for the overall surplus during the first half of the sample period than in the second, as was the case for these two periods in Table 1. As can be seen from the breakdown between revenues and outlays, though, this strengthened

\footnotetext{
${ }^{6}$ I exclude from changes in expenditures induced changes in debt service, as these are attributable to both revenue and expenditure policy changes and a breakdown is not available.

${ }^{7}$ Because policy revisions between the winter and summer take effect starting midway through the current fiscal year, I reduce the weight on the current fiscal year by one-half and increase weights on subsequent years correspondingly. That is, if $\delta$ is the discount factor, the weights applied to revisions between summer and winter are $x, x \delta, x \delta^{2}, \ldots, x \delta^{5}$, while the weights applied to revisions between winter and summer are $.5 y, .5(y+y \delta)$, $.5\left(y \delta+y \delta^{2}\right), \ldots, .5\left(y \delta^{4}+y \delta^{5}\right)$, where $x$ and $y$ are determined so that the weights for the six fiscal years sum to 1 .

${ }^{8}$ The results for alternative discount factors, ranging from .1 to .67 , are qualitatively similar to those presented in Table 2.

${ }^{9}$ I use the annual surplus measure, rather than the quarterly NIPA surplus used in Table 1, to maintain consistency with the surplus, revenue and expenditure policy measures here, which are based on the actual federal budget.
} 
responsiveness since 1993 is due to behavior on the revenue side, as outlay responses are relatively similar (and not statistically different) during the two halves of the sample period.

The responsiveness of revenues to the budget surplus since 1993 is quite consistent with the pattern of major tax legislation, with the tax increase of 1993, occurring at a time of large budget deficits, being followed by a small tax cut in 1997, when the deficit was much smaller, and a large tax cut in 2001, when the budget was in surplus. What is, perhaps, more surprising is that this same increased sensitivity does not also show up on the outlay side. After a period of effective downward pressure on discretionary spending, associated with the multi-year spending caps initiated by the Budget Enforcement Act in 1990 and extended by legislation in 1993 and 1997, the decade closed with a surge in "emergency" spending in 1999 and 2000, meant to override the spending caps, with the caps simply being ignored thereafter, even before the postSeptember 11 surge in national security spending.

Part of the explanation for this lack of the expected empirical finding may be the behavior of entitlement spending, which has been growing in importance over the years, or the conventions used to determine when spending policy has "changed." This is typically a more difficult task than is faced on the revenue side, where policy changes primarily just track actual legislative changes. To address each of these concerns, I consider, in Table 3 , the behavior of discretionary spending over the years. These data are available since fiscal year 1962, so the first observed change in fiscal year spending is for 1963. The table relates actual year-to-year changes in discretionary spending to the prior year's GDP gap ${ }^{10}$ and budget surplus, all relative to full-employment GDP. This exercise has two advantages over the examination of outlays in Table 2: it focuses only on discretionary spending, and considers actual spending changes, rather

\footnotetext{
${ }^{10}$ The results were similar using the GDP gap for the last quarter prior to the fiscal year, rather than for the previous fiscal year.
} 
than changes in forecast spending. It also has the disadvantages of being at an annual frequency, making an evaluation of countercyclical responses problematic, and including changes in spending that might be the automatic result of cyclical factors. This second problem should not be a major concern, though, given that the focus is on discretionary spending.

For the full sample, in Table 3's first column, the coefficients of the GDP gap and the budget surplus both have the predicted sign, but both are small and neither is estimated precisely. In all specifications and time periods, the GDP gap was quite insignificant, suggesting a weak relationship at the annual frequency. Thus, the remaining columns present estimates excluding this variable, for the full sample period and three subperiods, the last two, 1984-92 and 19932001, corresponding to the two recent sample periods examined in Tables 1 and 2. The results in these columns do suggest a recent increase in the responsiveness of discretionary spending to the budget surplus, with this relationship being statistically significant since 1993. But, with only nine observations for this period, one should not make too much of these results. There may, indeed, have been a recent breakdown in fiscal discipline, but it is difficult to quantify the importance of this phenomenon using standard statistical techniques.

\section{Summary: How Active Has Policy Been?}

The results presented thus far are subject to a collection of empirical limitations, which have been discussed in the context of their presentation. But, taken together, they suggest that fiscal policy has been responsive both to cyclical factors and conditions of fiscal balance during recent decades. The cyclical responsiveness may be something of a surprise, given a general perception that attempts at countercyclical fiscal policy have been poorly timed. Indeed, one can cite instances in which timing has been poor, but there are other cases, for example the advance tax reduction checks sent during the late summer of 2001, when fiscal changes occurred at the 
right time, even if, as seems likely for the 2001 tax cut, the countercyclical thrust occurred by coincidence at least as much as by design.

Still, the magnitude and timing of discretionary responses is only part of the story concerning the efficacy of fiscal policy as a tool for macroeconomic stabilization. An important additional step involves the link from fiscal changes to behavioral responses, an issue about which there has been much recent debate and to which I return below. Also, the automatic responses of the budget to the economic cycle, purged from consideration above in order to measure the strength of discretionary policy actions, are nonetheless a component of stabilization policy and worthy of consideration, particularly if skepticism remains about the viability of discretionary policy. I turn to this issue next.

\section{Automatic Stabilizers}

As economic activity fluctuates, so does federal spending and, especially, federal tax revenues. Traditionally, these fiscal changes have been seen as automatic stabilizers, stimulating aggregate demand as income falls and reigning in demand and income rises. But changes in the composition of revenues and spending over the postwar period have been substantial. What impact have these changes had on the strength of automatic stabilizers in the United States?

One method of measuring the strength of automatic stabilizers is to relate the gap between the full-employment surplus and the unadjusted surplus to the contemporaneous gap between GDP and full employment GDP. The coefficient of this relationship indicates the magnitude of the response of the surplus to GDP that is embodied in the CBO's calculation of the full-employment surplus. For the full sample of quarterly data used above in Table 1, this coefficient (in a regression not shown) is .350, indicating that fluctuations in the federal budget surplus are equal in magnitude (and of opposite sign) to around one-third of contemporaneous 
output fluctuations. One can also look at the coefficient for individual years to see how this relationship has changed over time. As these annual estimates are somewhat unstable, one can get some idea of the evolution of the coefficient by looking at a five-year weighted moving average of individual year estimates. This series of smoothed coefficients is shown in Figure 1. ${ }^{11}$ The figure shows fluctuations in the relationship over time, but no obvious trend, other than perhaps a drop from the high values of the 1950s. But this approach based on aggregate measures of the output and surplus gaps does not allow one to determine whether these fluctuations relate to actual changes in the tax structure or automatic spending rules or to the position in the cycle or other factors for which one might wish to control. To learn more, it is helpful to use a more micro-level approach, estimating how, based on tax and spending rules, the liabilities of taxpayers and the level of government spending would have changed in each year in response to a change in output.

Auerbach and Feenberg (2000) used this latter approach to estimate the impact of output fluctuations on individual tax payments. Figure 2 updates the main results of that study, using the same methodology with minor adjustments and extended to include later years. The figure includes calculations for even years between 1960 and 1966, and every year thereafter through 1997. ${ }^{12}$ For each year, the calculation is based on that year's NBER TAXSIM model based on a file of individual income tax returns, using a "tax calculator" to estimate the impact on tax liability of changes in tax-return components of income and deductions. To calculate the value for a particular year, one carries out a hypothetical experiment in which all income and incomerelated deduction items on each tax return in that year are increased by 1 percent, meant to simulate

\footnotetext{
${ }^{11}$ The moving average weights are (1/9, 2/9, 1/3, 2/9, 1/9); the figure also excludes 1991, because of the anomalies associated with Operation Desert Storm.

${ }^{12}$ I am extremely grateful to Dan Feenberg for providing these estimates and those presented below in Figure 3.
} 
a 1-percent change in aggregate income spread neutrally across the population. Then, all the individual tax changes are added together and divided by the sum of assumed income changes for that year. The result is the ratio of the aggregate change in taxes to the aggregate change in income. The first series of Figure 2 presents estimates of this ratio for the income tax, excluding the Earned Income Tax Credit (EITC). We might expect this ratio to have fallen during the 1960s and 1970s, with the general decline (at least until the 1990s) of top marginal tax rates associated with major legislation in 1964, 1981, and 1986. However, the two years in which the ratio is highest are 1980 and 1981. The explanation lies in the high inflation of the 1970s and early 1980s, with bracket creep (not eliminated from the tax system until 1985) pushing taxpayers into higher brackets. The trend reverses beginning with the 1981 tax cut, as the ratio declines gradually into the early-1990s.

The second series in Figure 2 repeats the exercise of the first series, but holds the distribution of income constant at that of the 1980 tax year, to determine whether changes in the responsiveness of the tax system over time are associated with the well-documented shifts in the income distribution. One implements this hypothetical experiment by applying the tax law for each respective year to the 1980 sample, with incomes and income-related deductions adjusted to reflect the ratio of that year's aggregate adjusted gross income to the adjusted gross income for 1980 . We might expect this series to exhibit less sensitivity to the cycle in recent years by giving less weight to income in higher marginal tax brackets, but the impact of this adjustment is trivial.

The third series in the figure is a reprise of the first, with varying income distribution, but now the EITC and payroll tax are added. Adding the EITC alone (not shown) has no effect until its 1975 enactment, and a very small effect for the remainder of the period, never adding more than 1 percentage point to the overall response for the aggregate taxpaying population considered in this 
figure. The payroll tax adjustment accounts for only the employee portion, consistent with the assumption that the fluctuation in before-tax income does not affect the relative incidence of the payroll tax on employer and employee. ${ }^{13}$ The effect of the payroll tax over time incorporates two factors, both of which increase its magnitude. First, the payroll tax has risen over time. Second, the rapidly rising payroll tax ceiling has made more taxpayers subject to the payroll tax on marginal income changes. Overall, the payroll tax increases the tax response substantially, particularly in later years, when it accounts for roughly one-sixth of the overall tax response.

The final series shown in Figure 2 takes into account the indirect effects of inflation on tax payments. The existence of a short-run Phillips curve implies that a decline in the rate of economic activity, as represented by a rise in the unemployment rate, will be associated with a fall in the inflation rate. As discussed above, inflation raised the real value of taxes paid before 1985, so a reduction in the rate of inflation would have decreased this effect, adding to the stabilizing impact of the tax system. This effect is incorporated in the calculation by assuming that the same uniform 1percent shock to real income induces a 0.5 -percent shock to the price level, for a total increase in each individual's nominal income of 1.5 percent. The impact of this additional effect is, as expected, to raise the tax response in the years prior to 1985.

Regardless of which of the series in Figure 2 that one considers, 1981 stands as the year in which the individual tax system absorbed the highest share of marginal income changes. The payroll tax imparts an upward trend from the early 1980s on, while the lack of indexing raises values for the period prior to 1985 . The overall picture is one of very little net change over the full period, as the effects of particular changes have tended to cancel each other out. The tax response in 1997 is roughly what it was in 1960.

\footnotetext{
${ }^{13}$ In principle, the change in the employer portion should also act as a cushion, but the impact would be more indirect, akin to that of other business tax payments.
} 
These results offer a somewhat different pattern than those in Figure 1, although that figure also shows a relative peak around 1981, a rise in the early 1990s, and relatively little trend in responsiveness over time. One important source of the difference between the figures is coverage: the personal income and payroll taxes covered in Figure 2 represent the most important automatic stabilizers in the United States, but there are other components that are omitted. Figure 1 covers the business and excise taxes excluded from calculations for Figure 2, as well as expenditure side responses, notably unemployment compensation. Also, the data used to produce Figure 1 take into account changes in the size of the taxpaying population, while those used for Figure 2 do not. These differences explain why the fiscal responses in Figure 2 are smaller than those in Figure $1^{14}$, and may also explain differences in year-to-year movements. Still, both figures suggest that the potential role of the fiscal system as an automatic stabilizer is not markedly different than it was decades ago.

The magnitude of these automatic fiscal adjustments, though, indicates only a potential for stabilization. The actual impact on aggregate demand of these fiscal changes, like the impact of the discretionary changes discussed above, depends on behavioral responses, in this case of household consumption expenditures. There has been considerable discussion in the literature about the responsiveness of households to temporary tax changes, starting with the recognition that consumption responses to temporary changes should be smaller than those to permanent changes — perhaps extremely small—among households with long-term planning horizons.

Indeed, Shapiro and Slemrod (2001) found in a survey that a small minority of households (22 percent) planned to spend the advance tax refunds sent in 2001 . On the other hand, econometric studies of responses to predictable changes in social security taxes and tax

\footnotetext{
${ }^{14}$ Figure 1 presents tax offsets as a share of GDP, while those in Figure 2 are relative to the tax-return concept of Adjusted Gross Income (AGI), which is about 60 percent of GDP. Thus, an offset in Figure 2 represents an absolute response that is about 60 percent the size of an equal percentage offset in Figure 1.
} 
refunds (Parker 1999 and Souleles 1999, respectively) find a larger consumption response, and a still larger consumption response — as high as 90 percent—-has been estimated for the phased-in Reagan tax cuts of the early 1980s (Souleles 2002). The data used for these studies typically are inadequate to determine whether the consumption response would be different for the highincome individuals who pay such a large share of income taxes and hence would bear a large share of tax fluctuations. One might expect a much lower response among this group than among the general population, if liquidity constraints were causing the large consumption response. But the literature has not provided a strong link between excess consumption sensitivity and liquidity constraints, nor has it provided clear evidence of a smaller consumption response at higher incomes. Thus, although theory suggests that the overall impact on consumption could be substantially less than the automatic tax adjustments shown in Figure 2, some recent estimates indicate large consumption responses. But the reasons for such large estimated responses are not well understood, and hence it is unclear whether they would also apply to changes in tax payments induced by cyclical fluctuations. ${ }^{15}$

However, there is another potential way in which the tax system can act as an automatic stabilizer that has generally been overlooked. Automatic stabilizers have typically been conceived in relation to aggregate demand but, to the extent that employment levels are also determined by labor supply conditions, a tax system with rates rising with respect to income might also serve to stabilize output. Falling output, in reducing marginal tax rates, could encourage greater labor supply, with rising output and marginal tax rates having the opposite effect. Moreover, the temporary nature of the change in income, which works against the effectiveness of demand-

\footnotetext{
${ }^{15}$ Kniesner and Ziliak (2002) come closer to answering this question by estimating a large consumption response directly to variations in individual disposable income. However, they do not estimate the response to tax payments separately, and the variations in disposable income they consider are conditional on aggregate consumption and hence purged of cyclical movements.
} 
side stabilization, reinforces the supply-side impact. If leisure is a normal good, permanent increases in the after-tax wage have an income effect that discourages labor supply and works against the substitution effect of the wage change. But this offsetting income effect is largely absent from temporary changes.

How large an effect might such marginal tax rate changes have? If we focus only on firstround effects (i.e., ignoring subsequent effects of the induced increase in labor supply on the before-tax wage and marginal tax rate), the net stabilization effect will equal the product of two terms: the impact of the initial change in output on the after-tax wage rate though the changing marginal tax rate, and the change in labor income from the induced labor supply response. As shown in Auerbach and Feenberg (2000), this product is roughly equal to the product of the change in the marginal tax rate with respect to a unit proportional change in income, $d t / d \ln Y$, and a relevant labor supply elasticity, say $\eta$, that may be relatively large, reflecting not only the absence of an income effect but also the possibility of intertemporal labor substitution.

Figure 3 presents estimates of the impact of income changes on marginal tax rates, averaged over the population in proportion to labor income. Like the series in Figure 2, these are extensions of results presented in Auerbach and Feenberg (2000). The series in the figure correspond to two of those in Figure 2, for the income tax alone without the EITC, and for the income tax with the EITC plus the payroll tax. As one would expect, the patterns in this figure are similar to those in Figure 2, with the sensitivity of marginal tax rates peaking around 1981, when marginal rates peaked, falling thereafter and again after 1986, as a result of the legislated flattening of the marginal rate distributions in those years. The EITC effect (not shown separately from that of the payroll tax) is small, slightly reducing the marginal tax rate sensitivity (due to individuals passing out of the phase-out range with rising income). The impact of the 
payroll tax is more significant and counter to its impact on the demand side. Here, it reduces the tax system's impact; around the payroll tax ceiling, the marginal tax rate falls sharply as income rises. $^{1617}$

Overall, the potential stabilizing impact through marginal tax rate changes has fallen considerably since the early 1980s. Even now, though, the implied effect is about .07 times the labor supply elasticity, potentially close in magnitude to the consumption response just estimated. Thus, to the extent that cyclical fluctuations in employment are an equilibrium phenomenon - generated not simply by changes in labor demand, but by interactions of supply and demand — one should not ignore the role of marginal tax rates in stabilizing output.

In summary, automatic stabilizers have long been suggested to be an effective tool for overcoming the lags of discretionary policy. According to the traditional approach to estimating the tax system's capacity for automatic stabilization, the U.S. tax system is roughly as effective as in the 1960s, though less effective than it was two decades ago. But there is an additional issue that must be confronted regarding automatic stabilizers, that their ability to stimulate aggregate demand depends on the transmission of temporary after-tax income shocks to consumption. Despite recent contributions to the literature, the strength of this consumption effect is still not clear. On the other hand, there may be an impact on the supply side that has typically been ignored, that provides a stronger impact on output, particularly in the case of temporary tax shocks. The relative importance of automatic stabilizers on the demand and supply sides remains to be determined.

\footnotetext{
${ }^{16}$ The measured effect may be somewhat overstated, because it does not take into account the present value of benefits generated by marginal payroll taxes. But this offset would be far from complete for households near the payroll tax ceiling, given the progressivity and other features of the benefit formula.

${ }^{17}$ As discussed in Auerbach and Feenberg (2000) incorporating the added change in nominal income due to inflation magnifies the measured effect before 1985 .
} 


\section{How Effective Has Fiscal Policy Been?}

Above, I presented evidence on the cyclical responsiveness of discretionary fiscal policy, as measured by changes in spending and tax revenues effected through explicit policy changes. This evidence suggests that these fiscal changes have been countercyclical, making them potentially helpful to the cause of macroeconomic stabilization. Indeed, the cyclical responsiveness appears to have increased during the past decade.

As the discussion of the previous section on automatic stabilizers reminds us, though, one must look beyond simple changes in revenues and spending to the impacts on output. This is especially important on the revenue side, for revenue changes, in themselves, have no impact on GDP - they work only through the behavioral responses they elicit. In terms of household consumption - the main response considered thus far - the primary issue is how large the response will be. But, for the other component of private domestic spending - investment - the issues are more complicated.

\section{Stabilization and Investment}

Although spending on durable investment goods may depend to a certain extent on current after-tax cash flow, it also depends on expectations of future profitability and, importantly, future tax policy. The issue of intertemporal substitution, raised above in the discussion of the potential labor supply response, is even more relevant here, in considering the purchase of long-lived durable investment goods. Changes - or expected changes—in the effective price of durable goods potentially can exert a powerful impact on investment spending, in a manner that is not well captured by concurrent changes in business tax collections.

A good illustration of this distinction is afforded by the 2002 stimulus bill's change in investment incentives. The primary change was the introduction of expensing (instead of regular 
depreciation) for 30 percent of purchases of investment goods with tax lifetimes of 20 years or less, for a period of three years. As a form of accelerated depreciation, this policy, mechanically, would have a larger revenue effect in the short run than in the long run, even if it were enacted permanently. The additional deductions for future investment would be offset by the smaller deductions on prior investment that had already been partially expensed. Thus, the annual revenue losses would not provide an accurate picture of the tax incentives for capital investment, which would remain constant after enactment. As enacted, though, the provision is more complicated to analyze, for it makes capital less attractive to have after three years, but also encourages a shift in the timing of investment to occur within the three-year window. The plausibility of the provision's three-year life span is also at issue in determining whether firms treat this "temporary" incentive as permanent. Actual behavior will reflect expectations about the future, not statutory language, and the past practice of countercyclical investment incentives will influence the formation of these expectations.

The role of current tax provisions and expectations can be described using the standard Hall-Jorgenson user of cost of capital, which provides a measure of the required gross, before-tax return to capital and hence a measure of the incentive to use capital in production. For a constant tax system, the user cost is:

$$
c=\frac{q}{p}\left(\rho+\delta-\frac{\Delta q}{q}\right) \frac{1-k-\tau z}{1-\tau}
$$

where $p$ is the price of output, $q$ is the price of new capital goods, $\rho$ is the nominal discount rate, $\delta$ is the exponential rate at which capital actually depreciates, $k$ is the investment tax credit, $\tau$ is the corporate tax rate, and $z$ is the present value of depreciation allowances per dollar of capital 
purchased. According to this theory, taxation affects the incentive to invest in a straightforward manner, with increases in the corporate tax rate raising the cost of capital (assuming that $z<1$ ) and increases in the investment tax credit or the present value of depreciation allowances lowering the cost of capital. If one modifies the assumptions to incorporate changes in tax policy, the user cost of capital becomes (see Auerbach 1983):

$$
c=\frac{q}{p}\left(\rho+\delta-\frac{\Delta[q(1-\Gamma)]}{q(1-\Gamma)}\right) \frac{1-\Gamma}{1-\tau}=\frac{q}{p}\left(\rho+\delta-\frac{\Delta q}{q}\right) \frac{1-\Gamma}{1-\tau}+\frac{q}{p} \frac{\Delta \Gamma}{1-\tau}
$$

where $\Gamma$ equals the sum of the investment tax credit and the present value of tax savings from depreciation deductions. ${ }^{18}$

According to expression (2), the price of capital goods is effectively the underlying price, $q$, multiplied by a factor that accounts for the tax benefits associated with the purchase of capital, $\Gamma$. The presence of the additional term on the right-hand side of (2) means that there are now two ways in which tax policy may affect investment. First, as already discussed, it can affect the overall level of desired capital, given a constant tax regime. Second, if the regime is expected to change, it may encourage firms to alter the timing of their capital purchases. Indeed, a change such as the expected elimination of an investment tax credit has a powerful effect on the user cost as computed from expression (2), for it induces a huge capital gain at the time of the credit's elimination.

To study these timing effects, though, a model that assumes instantaneous capital stock adjustment is inadequate. Theoretical models that incorporate adjustment costs commonly

\footnotetext{
${ }^{18}$ This sum equals $k+\tau z$ if $\tau$ is constant over time. If $\tau$ is expected to change over time, then the present value of tax savings from depreciation deductions is not the simple product of the current value of $\tau$ and the present value of depreciation deductions, $z$.
} 
assume that the cost of adjustment rises at an increasing rate with the level of capital expenditures, implying that it is desirable for the firm to spread the expenditures over time. Moreover, expectations of future changes in the incentive to use capital in production lead to immediate changes in investment, in order to minimize the adjustment costs incurred in closing the gap between the current and future desired capital stocks.

As shown in Auerbach (1989) and Auerbach and Hassett (1992), optimal investment behavior in the presence of convex adjustment costs, which gives rise to Tobin's q theory of investment (e.g., Hayashi 1982), may also be characterized by a partial adjustment investment process in which the desired capital stock at date $t$ varies inversely with the weighted average of the current and expected future user costs of capital based on expression (2):

$$
c_{t}^{*}=E_{t} \sum_{s \geq t} w_{s-t} c_{s}
$$

where the weights, $w_{i}$, sum to unity and decline exponentially, at a rate that is inversely related to the size of adjustment costs; the more sluggish the investment response, the more the future matters.

Expression (3) for the weighted sum of user costs has some straightforward implications. If the user cost suddenly changed today — for example, because of a change in tax law designed to deliver the economy from recession — and this change were expected to last indefinitely, then the weighted average is simply the new current value (because the weights add to unity). However, if today's change in the user cost is not expected to persist—for example, because the change in tax law is expected to be temporary—-then the user cost relevant for current investment must reflect this anticipation. Generally, this will encourage even more current investment than if the incentive were expected to be permanent. 
The possible effects of temporary incentives can be illustrated with the new U.S. law. Table 4 summarizes the immediate fiscal stimulus for a representative asset for a variety of assumptions about the weight placed on future capital costs and the permanence of the tax change. The weights on future capital costs reflect a plausible range, based on the estimates in Auerbach and Hassett (1992). As the table suggests, there is a wide range of possible effects, depending on the technology of investment adjustment and the nature of expectations; and it is reasonable to assume that expectations would account for more than the statutory language, given the degree of policy activism in the past.

In a regression based on annual data for the period 1953-85, Auerbach and Hines (1988) found that the key variable in the user cost expression (2), $\frac{\Gamma}{1-\tau}$, was significantly affected by the unemployment rate, the rate of GNP growth, and the real interest rate. Some of the signs were consistent with countercyclical policy timing, but others were not, making the net stabilizing impact unclear. Further, one must also take into account the impact that such frequent policy changes had on investment in periods when stimulus was not being applied—when the expectation of an investment incentive might have depressed investment. Based on their empirical estimates of investment behavior, Auerbach and Hassett (1992) concluded that, over the period 1953-88, actual tax policy had destabilized business fixed investment. The period since then, until this year, has been one of quietude with respect to investment-oriented changes in the law, but not with respect to proposed changes, including a similar provision to that enacted this year proposed by the first President Bush in 1992, and the possibility of an incremental investment tax credit floated during the first year of the Clinton administration. Presumably, some of the investment fluctuations of the past decade represented reactions to tax changes that never occurred. 
While discretionary fiscal policy has proved problematic for stimulating investment, there are also problems associated with automatic stabilizers. As portrayed by the neoclassical investment theory, forward-looking investment behavior need not respond strongly to current cash-flow conditions. This prediction remains controversial, as the literature - motivated by theories of capital market imperfections and asymmetric information-continues to debate the importance of current cash-flow conditions for investment. To whatever extent cash flow does matter, income tax fluctuations, especially fluctuations in the corporate income tax, can cushion investment fluctuations, for they rise and fall with current profitability. But there are important limits to this cushion on the down side imposed by tax law asymmetries, notably the limits on the deductibility of losses and the corporate Alternative Minimum Tax (AMT).

The inability of corporations to get refunds for losses can loom very large in recessions. During the deep recession in the early 1980s, for example, Altshuler and Auerbach (1990) found that roughly one-fifth (weighted by assets) of the non-financial corporate sector was constrained in this manner, with an even larger number of firms not fully able to utilize investment tax credits for which some investment qualified at the time. Such restrictions have a mixed effect on the forward-looking incentive to invest, as the inability to deduct depreciation and other up-front incentives today is offset by the possibility that profits will be shielded by future losses. But, for cash-constrained firms, the negative effect is clear. Thus, the 2002 stimulus package also included a temporary, two-year provision that extended the number of prior years to which current losses could be "carried back" to offset past profits and get an immediate deduction for losses.

The corporate AMT has an effect similar to the limit on losses. It is more likely to bind (i.e., exceed a firm's regular tax liability) in periods of low profitability, as a firm's AMT 
liability is less sensitive to profit fluctuations than its regular tax liability. Like the limit on losses, the AMT represents a deviation from symmetric taxation that reduces cash flows during periods of low profitability. There are other asymmetries present in the tax code, working in the same direction, such as the limit on the use of foreign tax credits.

These various tax law asymmetries — which may have little economic justification and in any event have generally been enacted without consideration of economic effects - have, as the 2002 legislation illustrates, transferred a potential automatic stabilizer into the realm of discretionary policy. As the limits of discretionary policy are recognized, it certainly makes sense to give some serious thought to reforming these provisions permanently.

\section{Measuring Fiscal Policy's Quantitative Effects}

Taking account of all the channels through which discretionary fiscal policy has operated, is it possible to measure how effective it has been? In a recent investigation using time series methods, Blanchard and Perotti (1999) find that discretionary fiscal policy "works" in the sense that positive innovations to government spending increase subsequent output, as do negative innovations to tax revenues. In particular, tax reductions increase consumption. This means that discretionary policy could work, in that it has some effect on output and its components.

Also using time series methods, Romer and Romer (1994) conclude that actual discretionary fiscal policy worked in the right direction, which is consistent with the regressions above showing that discretionary policy has responded to the GDP gap. But they also estimate that discretionary fiscal policy's overall impact was minimal, compared to that of monetary policy. They infer from the size and timing of automatic fiscal stabilizers that these have had a more important impact than discretionary policy, but it is difficult to estimate the impact of automatic stabilizers directly, precisely because they are directly tied to output fluctuations. That 
is, while there may have been "natural experiments" for discretionary policy that can be used to estimate such policy's economic impacts, automatic stabilizers are, by their nature, driven by output fluctuations, so we will see little independent variation in them.

As discussed above, the current level of tax revenues is an inadequate summary measure of the expansionary thrust of fiscal policy. Even adjusting for the cycle, revenues can rise or fall as a consequence of extraneous factors (such as changes in the income distribution), and their composition and future path should also affect current consumption and investment decisions. Thus, estimates that cyclically adjusted tax revenues have tended to fall with increases in the output gap are not inconsistent with the conclusion that discretionary tax policy has destabilized investment, and estimates that discretionary policy has had a weak overall effect on output may reflect a combination of negative and positive impacts. Taken together, the evidence suggests that discretionary fiscal policy has effects but leaves us with little evidence that these effects have provided a significant contribution to economic stabilization, if in fact they have worked in the right direction at all.

\section{Discretionary Fiscal Policy and the Long-Run Budget Constraint}

The review above has emphasized that the efficacy of fiscal policy as a stabilization tool depends both on the government's ability to time policy changes and on the impact of these changes on aggregate activity. For consumption and investment, the impact of policy on current activity depends on expectations about the future as well. Tax cuts perceived to be temporary may undercut consumption responses; temporary investment incentives may work in the opposite direction, strengthening the immediate response (but also, potentially, weakening prior investment). As yet, I have not discussed how the fiscal environment may influence these expectations about the future. Recent contributions to the theoretical literature, and indeed 
recent policy arguments, have emphasized the importance of long-run considerations, suggesting that the scope for expansionary fiscal policy may be limited when long-run fiscal constraints are significant.

The government's long-run budget constraint is derived from the annual identity relating the budget surplus to the gap between revenues and spending plus the restriction that government debt cannot forever grow faster than the interest rate. This constraint may be written:

$$
B_{t}=\sum_{s=t+1}^{\infty}\left(\frac{1+r}{1+g}\right)^{-(s-t)} S_{s}^{p}
$$

where $B_{t}$ is the ratio of end-of-year national debt to GDP in the current year $t, S_{s}^{p}$ is the primary surplus in year $s$ as a share of that year's GDP, and $r$ and $g$ are the interest rate and the rate of economic growth, assumed for simplicity here to be constant. Under normal circumstances, $r>g$, meaning that it is not possible to "grow our way out of debt" passively by waiting for growth to provide the revenues needed for debt service; a higher level of national debt requires a compensating higher present value of future primary surpluses. This constraint always applies to government policy, whether or not it holds for current law. If expression (4) indicates an imbalance under current policy, this simply means that current policy is not sustainable.

The current state of fiscal policy, relative to one of fiscal balance, can influence the efficacy of discretionary policy in two ways. First, it can influence current policy, discouraging further expansion in the face of a preexisting fiscal imbalance, or encouraging it when the government's fiscal position appears more responsible. The estimates in Tables 1-3 above suggest that policy follows this pattern, at least if the previous budget surplus as a share of GDP provides some indication of the government's fiscal position. (I return to this question of 
measurement below.) Second, the government's fiscal position provides information about the set of feasible future policies. A situation of extreme imbalance, for example, suggests that a substantial reduction in spending, a substantial increase in tax revenues, or both will be needed in the future. ${ }^{19}$ Thus, a large current tax cut may have a less powerful impact on current consumption, if households view it as unsustainable and likely to be followed very quickly by a tax increase.

Indeed, many contributions to literature, surveyed recently by Giavazzi et al. (2000), have suggested reasons why a loosening of fiscal policy, adopted under such conditions of fiscal duress, may actually have contractionary economic effects. Normally, we would expect tax cuts to have positive wealth effects, increasing current consumption demand. Even recognizing the government's long-run budget constraint, which requires these tax cuts to be paid for by offsetting future policies, current consumers with finite horizons would expect some of the burden to be placed on future generations, leaving a net positive wealth effect for those alive today. As already discussed, the size of this wealth effect might be small, if the tax cut is assumed to be temporary.

But the wealth effect might even be negative, if the government must rely on very distortionary future taxes to recoup today's revenue loss, or if reaching some critical debt level or degree of fiscal imbalance triggers a crisis or a precipitous increase in tax burdens. In both instances, the full induced cost of future tax increases more than offsets the benefits of immediate tax cuts, even for current generations, who are then induced to curtail consumption and save more in preparation for the hard times to come. A similar logic applies to the effects of

\footnotetext{
${ }^{19}$ Included among the range of possible tax revenues are the implicit taxes on the holders of government assets associated with inflation - through seignorage and erosion of nominal debt — and outright default.
} 
government expenditures, and there is some international evidence from the output responses to fiscal policy that mechanisms like these may be at work (Perotti 1999).

The possibility of fiscal policy having expansionary effects certainly has come up in debates about U.S. fiscal policy in the 1980s and 1990s. The strong performance of the U.S. economy in the 1990s was often attributed by the Clinton administration to responsible fiscal adjustments, including the tax increase of 1993 and the extension of discretionary spending caps in 1993 and 1997. A common view appears to have evolved in policy discussions of 1990s fiscal policy that the positive effects worked through interest rate adjustments, the reduced crowding out and greater confidence in government inducing lower interest rates, which then spurred interest-sensitive private demand.

There is a long-running debate over the extent to which fiscal contractions actually do reduce interest rates significantly. But, whatever one's perspective on this debate, it is unclear how the theoretical literature explaining why fiscal contractions might expand output can be translated into the popular view of recent events that sees this expansion of output as occurring through a decline in interest rates. In particular, a fall in interest rates is not typically an element of the theory of expansionary fiscal contractions, and it is not evident how fiscal contractions might lead simultaneously to lower real interest rates and higher aggregate demand and output.

As a start, the conflict may be illustrated using a standard IS-LM diagram, as in Figure 4, with the real interest rate on the vertical axis and output on the horizontal axis. The standard analysis of a fiscal contraction, either through a tax increase or a spending reduction, starts with a downward shift in the IS curve from its initial position at $I S^{0}$, inducing a decline in aggregate demand and a decline in interest rates, with the decline in interest rates serving to cushion the decline in aggregate demand via a movement along the new, lower IS curve, labeled $I S^{1}$ in the 
figure. If the fiscal contraction conveys positive news about the future, this may stimulate current private sector demand, causing the downward shift in the IS curve to lessen, as represented by the intermediate curve labeled $I S^{2}$. There is no theoretical barrier to the IS curve actually shifting upward beyond the original curve, $I S^{0}$, if the positive impact on private demand is sufficiently strong. If this happens, then aggregate demand will indeed rise, but so will the interest rate, $r$. Adding inflation expectations to this basic framework merely deepens the problem. If the fiscal policy reduces the expected inflation rate, it reduces the nominal interest rate corresponding to any given real interest rate, thereby increasing money demand and causing a leftward-shift in the LM curve, from $L M^{0}$ to $L M^{1}$. This will require an even larger increase in the real interest rate for aggregate demand to increase.

The IS-LM model embodies a variety of restrictive assumptions, of course, but the difficulty of generating this combination of interest rate and output movements really just has to do with equilibrium in the capital market. If the demand for funds does not decline, then a fall in the real interest rate must be initiated by an increase in the supply of funds. What mechanism can generate this increased supply of funds and an increase in output at the same time? It is hard to see this combination as the result of a process beginning on the demand side, which would start with a reduction in the supply of funds via an increase in private or government consumption.

On the supply side, there could be an increase in labor supply (perhaps due to the income effect associated with expected higher tax payments in the future), which would increase output and, possibly, saving, but the increase in employment would tend to increase the productivity of capital and hence the demand for capital, too. The same would be true of a positive productivity shock (perhaps in some way associated with the salutary effects of the fiscal policy on economic 
stability) - it might increase output and the supply of funds, but it would also increase the demand for funds by firms seeking to take advantage of the higher productivity level. A temporary productivity shock would "work" in that it would increase output and saving as households sought to spread the benefits of the temporary shock over the future, but this seems rather far afield from what has been envisioned in policy discussions.

The analysis here is certainly not definitive, for there are many more scenarios and assumptions that a creative mind could employ. For example, if the fiscal contraction reduced the riskiness of future inflation (rather than just the level of expected inflation), this change might make long-term bonds relatively less risky than cash, reducing the demand for money and shifting the LM curve out in Figure 4, as to the position $L M^{2}$. The result could be an increase in output and a decline in real interest rates, indicated by the intersection of this curve and the curve labeled $I S^{2}{ }^{20}$ Or, perhaps, the "common wisdom" is based on confusion between nominal and real interest rates, for it is easier to understand how nominal rates might decline even as output increased as a consequence of a fiscal contraction. Finally, it is possible that a policy of fiscal contraction induces expectations of further fiscal contractions in the future, thereby lowering long-term interest rates enough to expand current output and short-term interest rates. ${ }^{21}$ Thus, $^{2}$ long-term rates would fall as current output rose, but short-term rates would rise.

As this discussion is meant to demonstrate, it is entirely possible that fiscal contractions might benefit the economy, and it is also possible that the United States in the 1990s offers us a positive demonstration. But the mechanism by which this is commonly supposed to have happened is not easily matched to a clear, compelling economic explanation. As we contemplate

\footnotetext{
${ }^{20}$ One might test this hypothesis by looking at movements in yields on indexed government bonds, which would not benefit from a reduction in inflation risk. Unfortunately, the United States began issuing indexed bonds only in 1997, after the Clinton administration's fiscal policy had largely been implemented.

${ }^{21}$ This possibility of this combination of effects is demonstrated analytically in Blanchard (1981).
} 
fiscal contractions in the future to respond to the major fiscal imbalance that exists, it is important to understand not only whether the 1990s fiscal contraction had expansionary effects, but also, if so, how this occurred.

\section{Accounting Conventions and Fiscal Policy}

Ultimately, government fiscal decisions must conform to the long-run budget constraint, but any particular year's policies need not, unless a long-run imbalance has precipitated a crisis requiring immediate action. The United States faces a long-term fiscal imbalance, giving the trajectory based on its current fiscal polices. The estimated size of this imbalance has fluctuated in the past decade, falling during the late 1990s and rising recently, but the main source of the imbalance — large, unfunded transfer programs, an aging population, and a continuing rise in health care spending per capita- has not changed. Based on the most recent $\mathrm{CBO}$ projections, Auerbach et al. (2002) estimate that the current imbalance, expressed as a permanent share of GDP by which the primary surplus would need to increase to satisfy expression (4) above, is between 4 and 8 percent. This is an enormous magnitude, larger as a share of GDP than any conventionally measured primary deficit during the postwar period.

It appears that government policy does respond to measures like the budget surplus, but the surplus itself is an extremely arbitrary measure. The most familiar illustration of this is the distinction between the unified federal budget and the budget that excludes "off-budget" items, most significantly the Social Security (OASDI) trust funds. In all but two recent fiscal years (1999 and 2000), the unified budget excluding off-budget items has been in deficit and the OASDI trust fund substantially in surplus. Moreover, as Figure 5 illustrates, the trends of the two surpluses are different. The Social Security trust fund has been growing as a share of GDP since it was roughly zero in 1984. 
Recognition that the Social Security trust fund is being accumulated to help pay for future benefits is now widespread among policy makers. Recent years' legislative machinations have given us new and arcane budget concepts like the "lock-box" in which the Social Security trust fund was to have been kept from the clutches of the fiscally irresponsible. But there is probably still not complete understanding how small the Social Security trust fund is relative to the unfunded commitments that appear nowhere on the conventional federal balance sheet, or that the annual accumulations in the trust fund are swamped by the annual accumulations in this implicit but very firm liability.

There have been attempts to broaden the federal budget presentation to make implicit liabilities more explicit. For example, the official U.S. budget documents released by the Office of Management and Budget (OMB) for fiscal years 1993-95 provided estimates of generational accounts, a recently developed and now widely used method of evaluating fiscal conditions. ${ }^{22}$ These presentations showed a substantial fiscal imbalance, represented by large looming burdens on future generations. Both $\mathrm{CBO}$ and, to a lesser extent, $\mathrm{OMB}$ have begun providing longerterm budget projections that, like those of the Social Security Trustees reports, show quite clearly the unsustainable policy trends.

Generational accounts and estimates of long-term budget gaps have become more familiar over time, but these projections still serve more as background information than as direct inputs to the policy process, which continues to rely on current and short-term deficit measures and, indeed, has come to rely more mechanically on these measures since the GrammRudman-Hollings legislation of the 1980s setting deficit targets. ${ }^{23}$ Given how much attention

\footnotetext{
${ }^{22}$ See, e.g., Auerbach et al. (1999).

${ }^{23}$ The primacy of the simple surplus measure is consistent with the fact that more forward-looking measures of the budget gap in alternative specifications of the policy equations in Table 2 were less successful in explaining policy changes.
} 
recent political debates about taxes and federal spending have given to the budget surplus, making changes to the "official" budget surplus, as through inclusion of some measure of accumulating liabilities, could have a major impact on policy.

As an illustration of what such a change might mean, the first column of Table 5 presents rough estimates of the size of the implicit liability of the OASDI system at the beginning of each year from 1997-2002, based on annual Social Security Trustees reports, other data, and a variety of assumptions that are described more fully in the appendix to this paper. This implicit debt is considerably larger than the reported national debt. ${ }^{24}$ The change from one year to the next in the implicit debt is a measure of the corresponding implicit deficit. This deficit, shown for each year in the table's second column, may be broken down into two components, one attributable to changes in the base year of the calculation and the other due to changes in population projections and economic projections from one year to the next. For example, the change in the implicit liability between 2000 and 2001 is estimated to be $\$ 769$ billion, of which $\$ 798$ billion—slightly more than the total implicit deficit — is attributable to the advance of a year in the date at which the calculation is being made. A small reduction of $\$ 29$ billion in the implicit deficit is attributable to an improvement in the forecast from the 2000 Trustees Report to the 2001 Trustees Report. For 2001, the total implicit deficit is estimated to be negative (i.e., there is an implicit surplus), because the impact of the base-year shift is more than offset by a substantial improvement in the forecast.

The deficit components attributable to changing forecasts are quite volatile, but the components due to base-year changes are not. These large, positive components reflect the fact that a large cohort in the population — the baby boom generation-is moving closer and closer to

\footnotetext{
${ }^{24}$ The magnitude of these estimates is roughly consistent with similar calculations for the period through 1997 presented in Goss (1999).
} 
retirement and the receipt of benefits. The closer in time these benefits are, the higher the present value of the liability to pay them. These annual accumulations in the OASDI debt swamp the annual accumulations in the OASDI trust fund, reminding us that, absent a continuing trend of improving projections like those of the last two years, a full accrual accounting of the OASDI system would show enormous annual deficits. Adding in the implicit liabilities of the Medicare system would substantially amplify this result.

Just as in the private sector, accounting conventions can have important real effects if the underlying information is not fully transparent. Even though it would directly cause no changes in the government's underlying liabilities, formally incorporating the accruing obligation to pay Social Security and Medicare benefits would convey much more clearly to policy makers and, perhaps more importantly, to those to whom policy makers are accountable, that the fiscal imbalance is not merely a "future" problem. It is hard to imagine that inclusion of deficit numbers like those in Table 5 in the annual presentation of the federal budget would not have an important impact on fiscal policy decisions.

\section{Conclusions}

Recent experience and research suggest a number of conclusions regarding the use and efficacy of discretionary fiscal policy:

(1) In recent years, U.S. discretionary fiscal policy appears to have become more active in response to both cyclical conditions and a simple measure of budget balance.

(2) Considerable uncertainty remains about how large an impact discretionary fiscal policy has on output. 
(3) There is little evidence that discretionary fiscal policy has played an important stabilization role during recent decades, both because of the potential weakness of its effects and because some of its effects (with respect to investment) have been poorly timed.

(4) Budgetary pressure may not only affect the fiscal response, but may also weaken the efficacy of expansionary fiscal policy if it is adopted. Conversely, contractionary fiscal policy may not restrict activity, and might even have a salutary effect on output. This possibility may be relevant for understanding the impact of fiscal policy in the 1990s, although the mechanism is unclear.

(5) Automatic stabilizers offer an alternative to discretionary fiscal policy. The automatic stabilizers embedded in the fiscal system have experienced little net change since the 1960s and have contributed to cushioning cyclical fluctuations. But the tax system has many attributes that weaken its potential role as an automatic stabilizer, particularly with respect to investment.

(6) The government's reported fiscal position, to which fiscal policy appears responsive, represents a very poor measure of underlying fiscal balance.

These findings suggest the need for continued caution in the use of discretionary policy, greater focus on making automatic stabilizers more effective, and the integration of better measures of fiscal balance into the discretionary policy process. And, of course, more research on the relevant issues. 


\section{References}

Altshuler, Rosanne, and Alan J. Auerbach, 1990, "The Significance of Tax Law Asymmetries: An Empirical Investigation," Quarterly Journal of Economics, February, 61-86.

Auerbach, Alan J., 1983, "Taxation, Corporate Financial Policy and the Cost of Capital," Journal of Economic Literature, September, 905-940.

Auerbach, Alan J., 1989, “Tax Reform and Adjustment Costs: The Impact on Investment and Market Value," International Economic Review, November, 939-962.

Auerbach, Alan J., 1994, "The U.S. Fiscal Problem: Where We Are, How We Got Here, and Where We're Going," in Stanley Fischer and Julio Rotemberg, editors, NBER Macroeconomics Annual, Cambridge: MIT Press, 141-175.

Auerbach, Alan J., 1999, "On the Performance and Use of Government Revenue Forecasts," National Tax Journal, December, 767-82.

Auerbach, Alan J., 2000, "Formation of Fiscal Policy: The Experience of the Past Twenty-Five Years", Federal Reserve Bank of New York Economic Policy Review, April, 1-15.

Auerbach, Alan J., and Daniel Feenberg, 2000, "The Significance of Federal Taxes as Automatic Stabilizers," Journal of Economic Perspectives, Summer, 37-56.

Auerbach, Alan J., William G. Gale, Peter R. Orszag, and Samara R. Potter, 2002, "The Budget Outlook and Options for Reform," in Henry J. Aaron, James Lindsey, and Pietro Nivola, editors, Agenda for the Nation, Washington: Brookings Institution Press, forthcoming.

Auerbach, Alan J., and Kevin Hassett, 1992, "Tax Policy and Business Fixed Investment in the United States," Journal of Public Economics, 47, 141-170.

Auerbach, Alan J., and Kevin Hassett, 2002, "Fiscal Policy and Uncertainty," paper presented at a conference on "Stabilizing the Economy" at the Council on Foreign Relations, July.

Auerbach, Alan J., and James R. Hines, Jr., 1988, "Investment Tax Incentives and Frequent Tax Reforms," American Economic Review, May, 211-6.

Auerbach, Alan J., Laurence Kotlikoff, and Willi Leibfritz, editors, Generational Accounting Around the World, Chicago: University of Chicago Press, 1999.

Blanchard, Olivier, 1981, "Output, the Stock Market, and Interest Rates," American Economic Review, March, 132-43.

Blanchard, Olivier, and Roberto Perotti, 1999, “An Empirical Characterization of the Dynamic Effects of Changes in Government Spending and Taxes on Output,” NBER Working Paper \#7269, July. 
Bohn, Henning, 1998, "The Behavior of U.S. Public Debt and Deficits," Quarterly Journal of Economics, August, 949-63.

Cohen, Darrel, Pernille Hanson, and Kevin Hassett, 2002, "The Effects of Temporary Partial Expensing on Investment Incentives in the U.S.," National Tax Journal, September, forthcoming.

Giavazzi, Francesco, Tullio Jappelli, and Marco Pagano, 2000, "Searching for Non-Linear Effects of Fiscal Policy: Evidence from Industrial and Developing Countries," European Economic Review, June, 1259-89.

Gokhale, Jagadeesh, Benjamin R. Page, and John R. Sturrock, 1999, “Generational Accounting for the United States: An Update," in Alan J. Auerbach, Laurence Kotlikoff, and Willi Leibfritz, editors, Generational Accounting Around the World, 489-517.

Goss, Stephen C., 1999, "Measuring Solvency in the Social Security System," in Olivia Mitchell, Robert Myers, and Howard Young, editors, Prospects for Social Security Reform, Philadelphia: University of Pennsylvania Press, 17-36.

Hayashi, Fumio, 1982, “Tobin's marginal $q$ and average $q$ : a neoclassical interpretation,” Econometrica, January, 213-224.

Kniesner, Thomas J., and James P. Ziliak, 2002, "Tax Reform and Automatic Stabilization," American Economic Review, June, 590-612.

Parker, Jonathan A., 1999, "The Reaction of Household Consumption to Predictable Changes in Social Security Taxes," American Economic Review, September, 959-73.

Perotti, Roberto, 1999, "Fiscal Policy in Good Times and Bad," Quarterly Journal of Economics, November, 1399-1436.

Romer, Christina D. and David Romer, 1994, "What Ends Recessions?" in Stanley Fischer and Julio Rotemberg, editors, NBER Macroeconomics Annual, 13-57.

Shapiro, Matthew D. and Joel Slemrod, 2001, "Consumer Response to Tax Rebates," NBER Working Paper \#8672, December.

Souleles, Nicholas S., 1999, "The Response of Household Consumption to Income Tax Refunds," American Economic Review, September, 947-58.

Souleles, Nicholas S., 2002, "Consumer Response to the Reagan Tax Cuts," Journal of Public Economics, July, 99-120. 


\section{Appendix}

This appendix provides a brief description of the data and methodology used to derive the implicit OASDI liability estimates reported in Table 5.

For each year from 1997 through 2001, the following procedure is used. Projected annual flows in and out of the OASDI system over a roughly 75 -year period are taken from that year's OASDI Trustees report. Projections of the male and female population at each age in each of these future years is taken from contemporaneous population projections, provided by Social Security from unpublished data. ${ }^{25}$ The projected taxes and benefits in each future year are allocated among cohorts using the tax and benefit profiles by age and sex from Gokhale et al. (1999). ${ }^{26}$ Then, to obtain an estimate of the OASDI system's "closed-group" liability-the liability to those already participating — only the taxes and benefits in each future year that have been allocated by this procedure to individuals who are at least 18 years old in the base year are counted. Finally, all of these included tax and benefit flows are discounted back to the base year using a nominal discount rate of 6 percent, a long-term discount rate consistent with recent Trustees assumptions. For 2002, the same procedure is used, except that 2001 population projections are used because the unpublished population projections for 2002 are not available.

The deficit for each year equals the next year's estimated liability minus that of the current year. The part of this deficit that is attributable to the change in base year is obtained by re-estimating the following year's debt using the current year's projections of flows and population.

\footnotetext{
${ }^{25}$ I am grateful to Seung An at the Social Security Administration for providing these data.

${ }^{26}$ If $a_{i}$ is the relative benefit (or tax) profile element for each cohort $i$ (where $i$ ranges over age and sex) and $p_{i t}$ is cohort $i$ 's population in year $t$, then the fraction of year $t$ 's benefits (or taxes) allocated to a particular cohort $j$ is $a_{j} p_{j t} /\left(\sum_{i} a_{i} p_{i t}\right)$.
} 


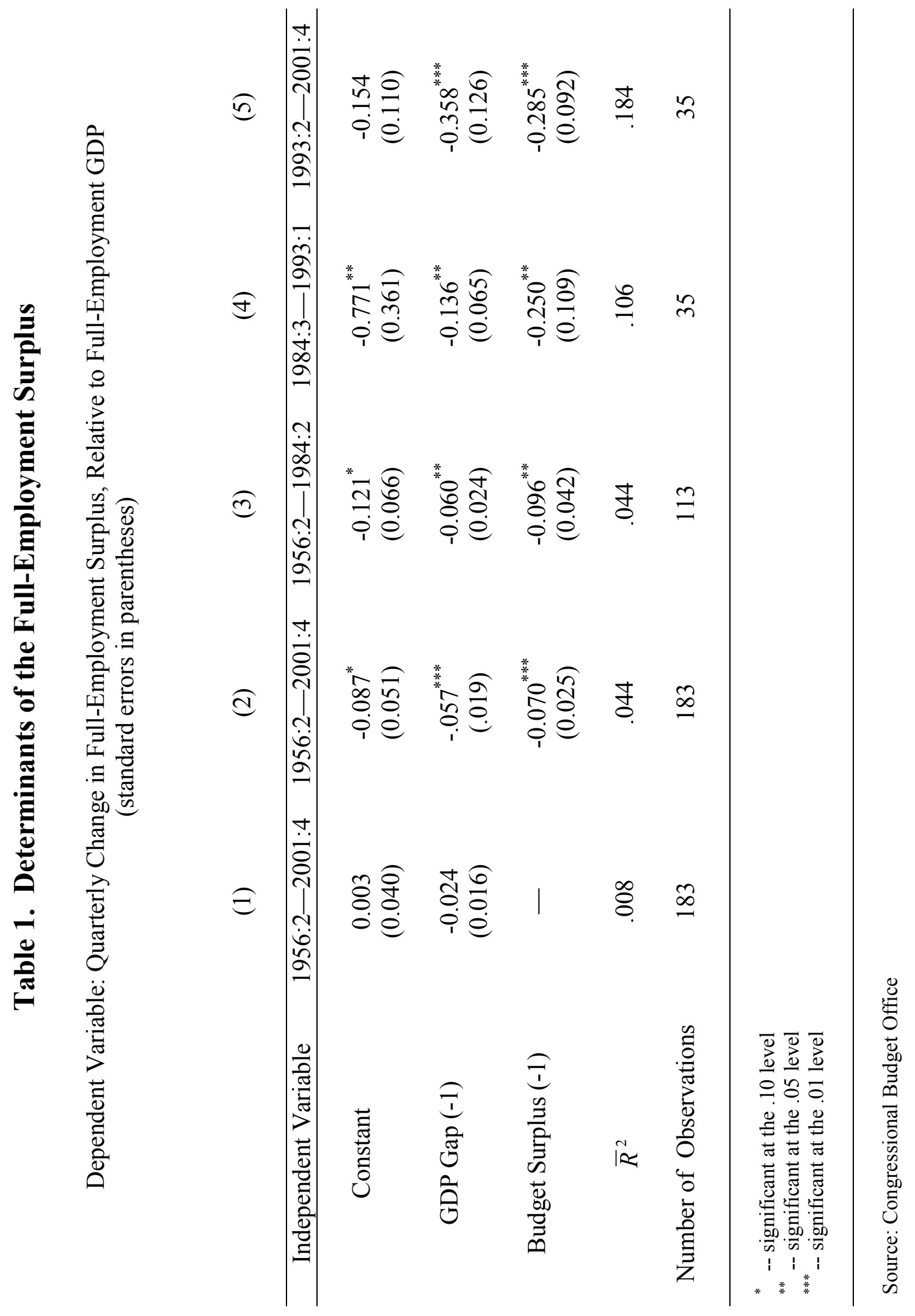




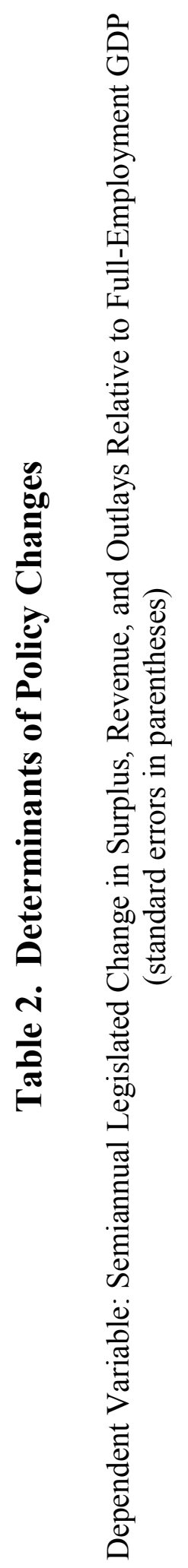

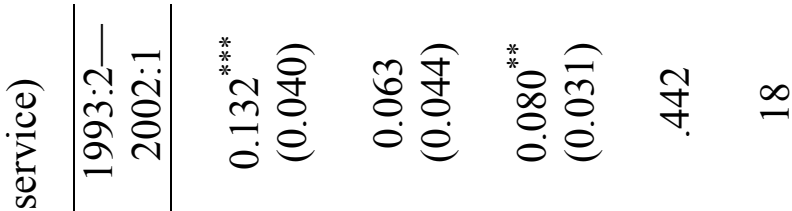

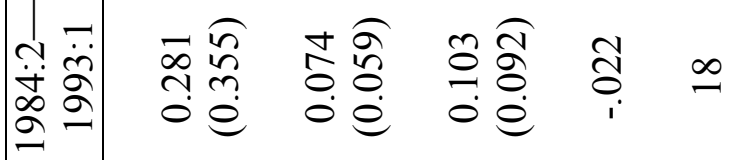

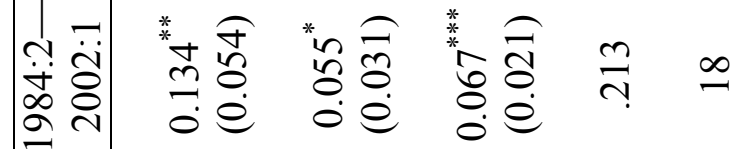

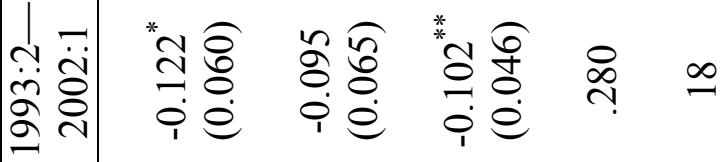

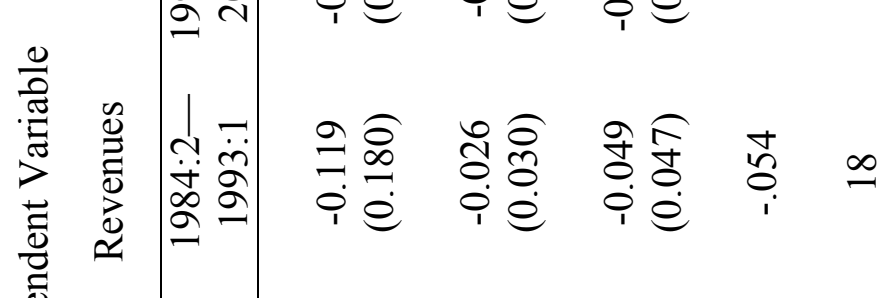

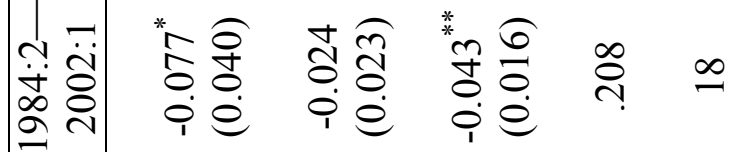
๑

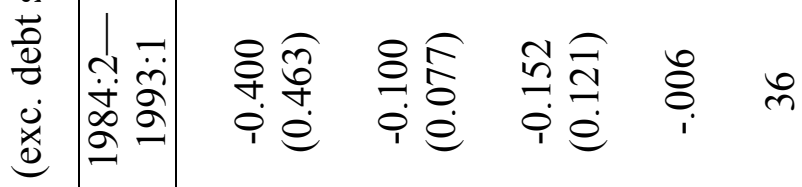
尝

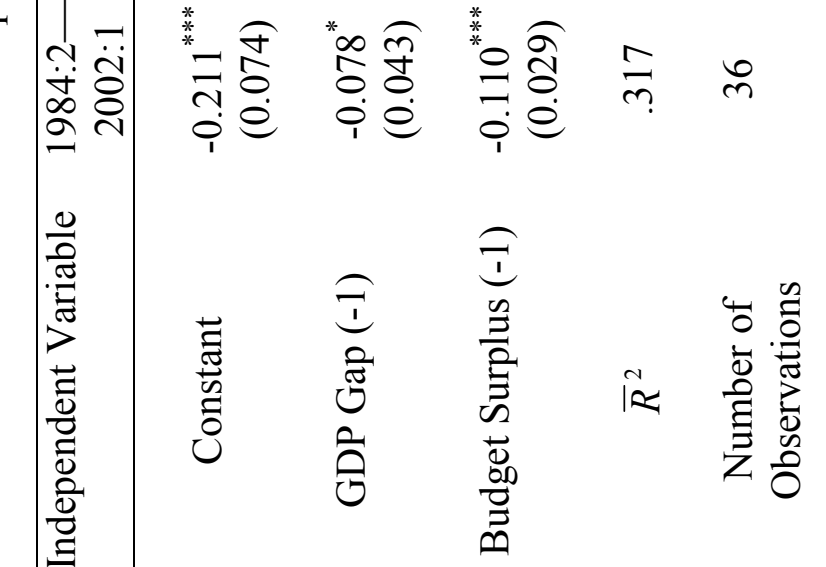




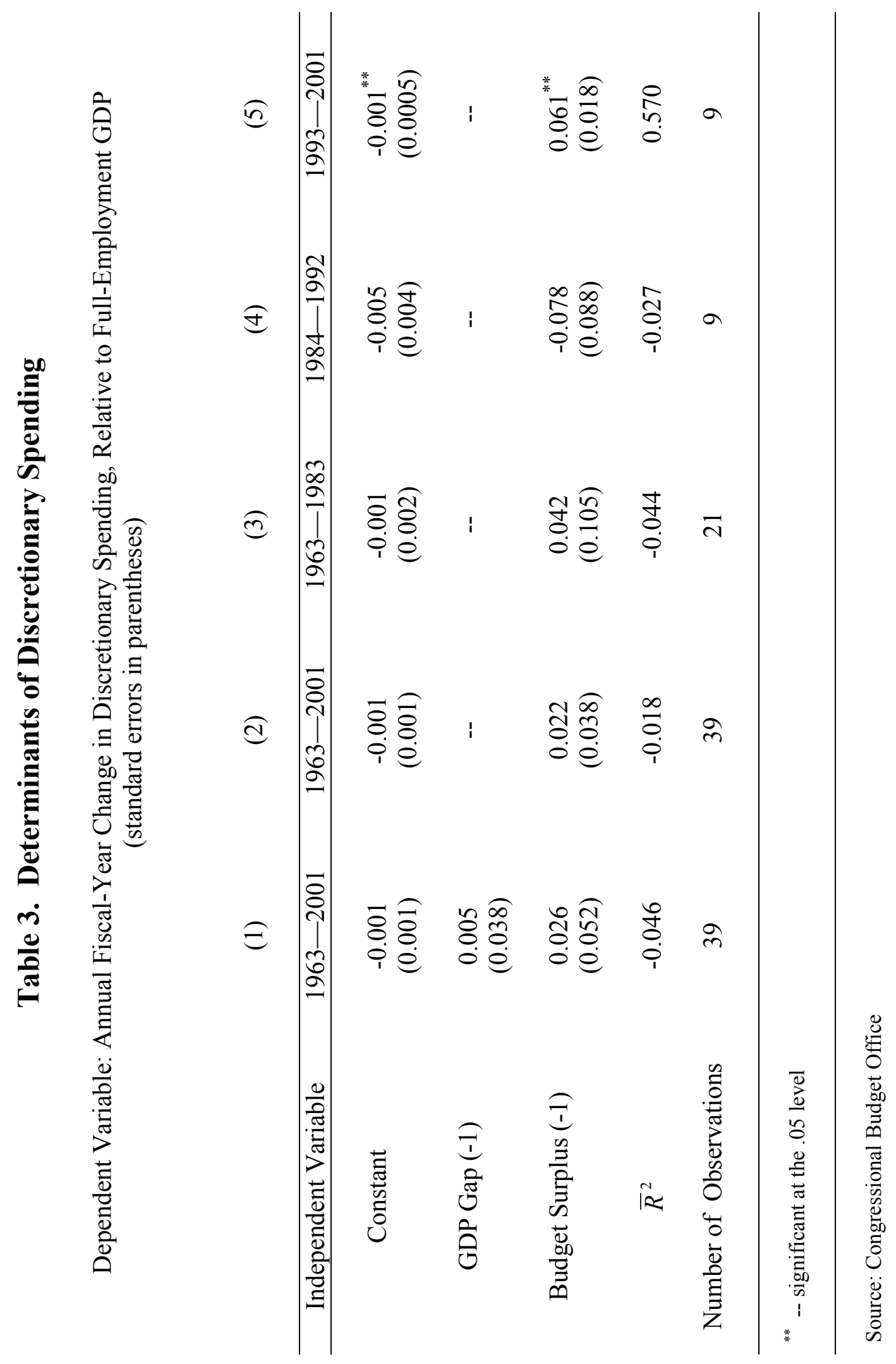




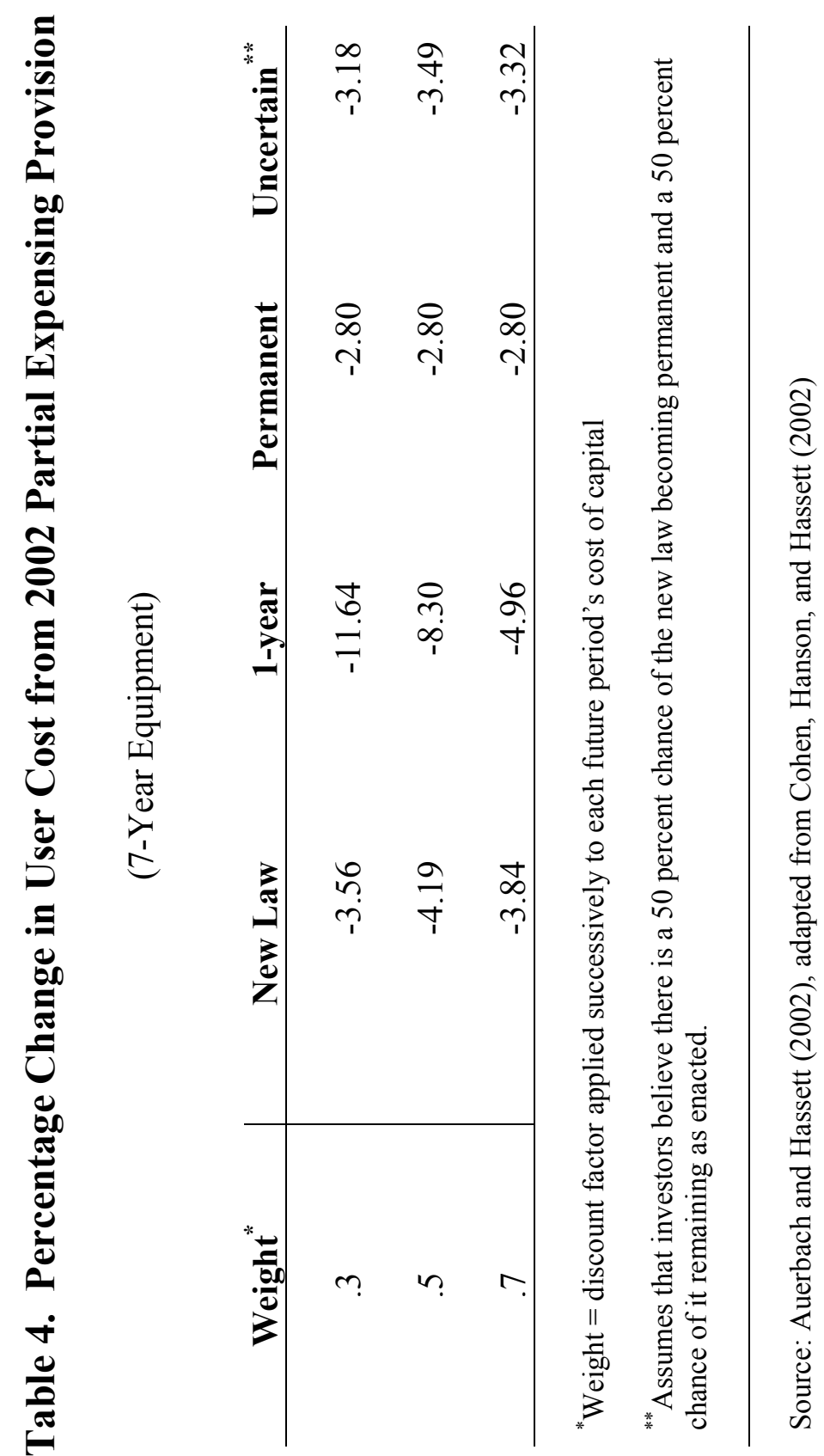




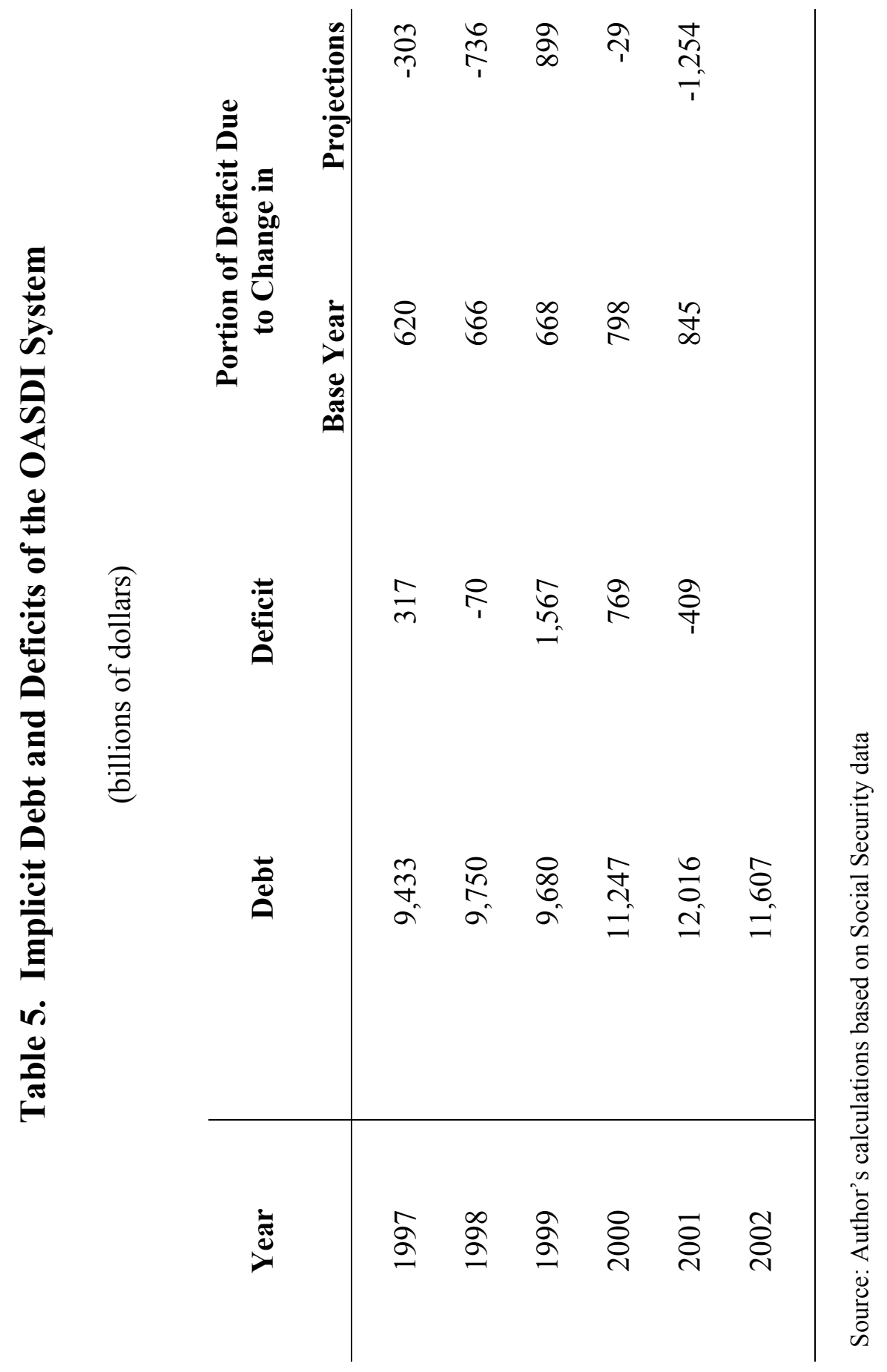




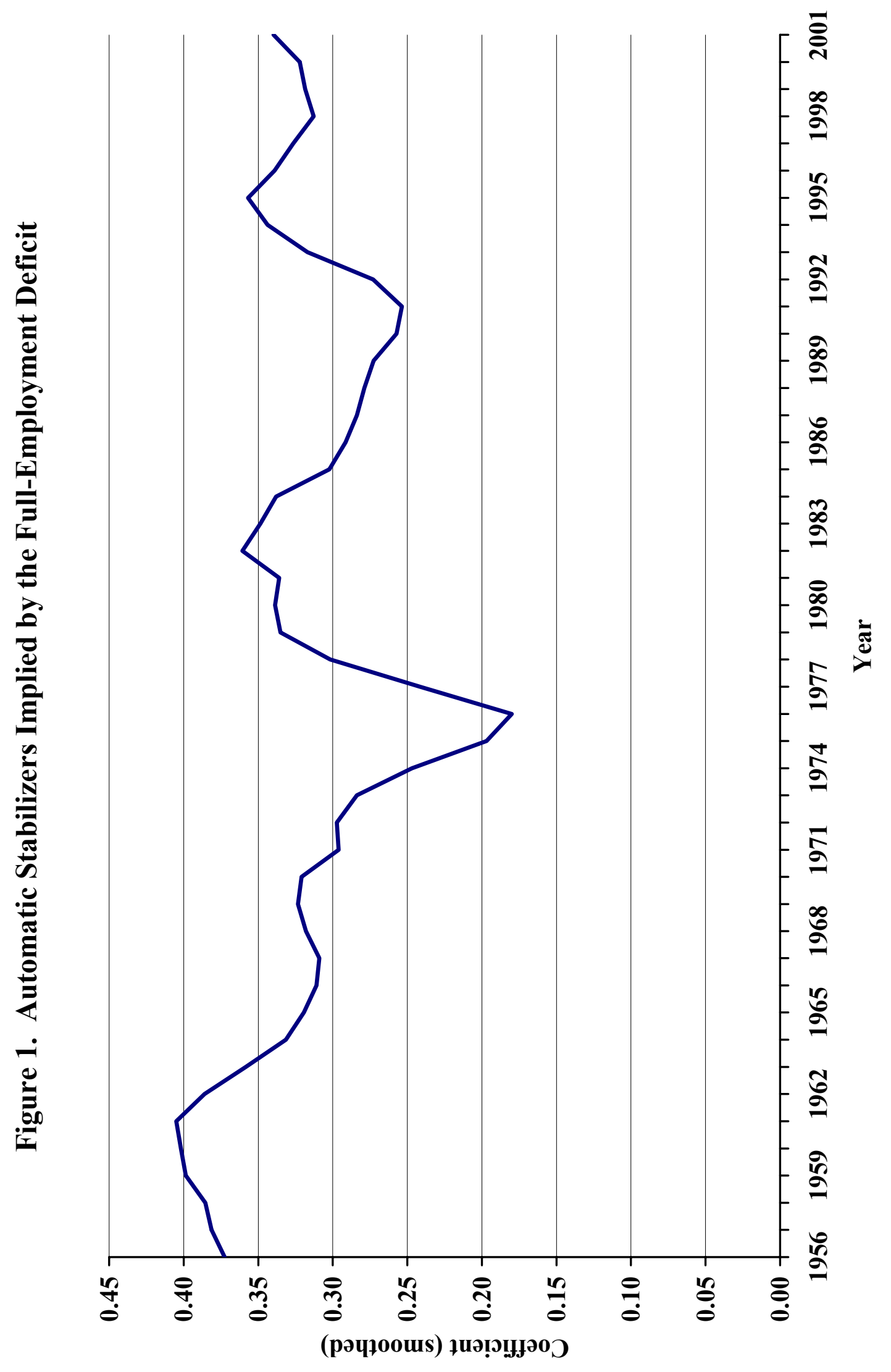

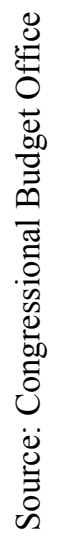




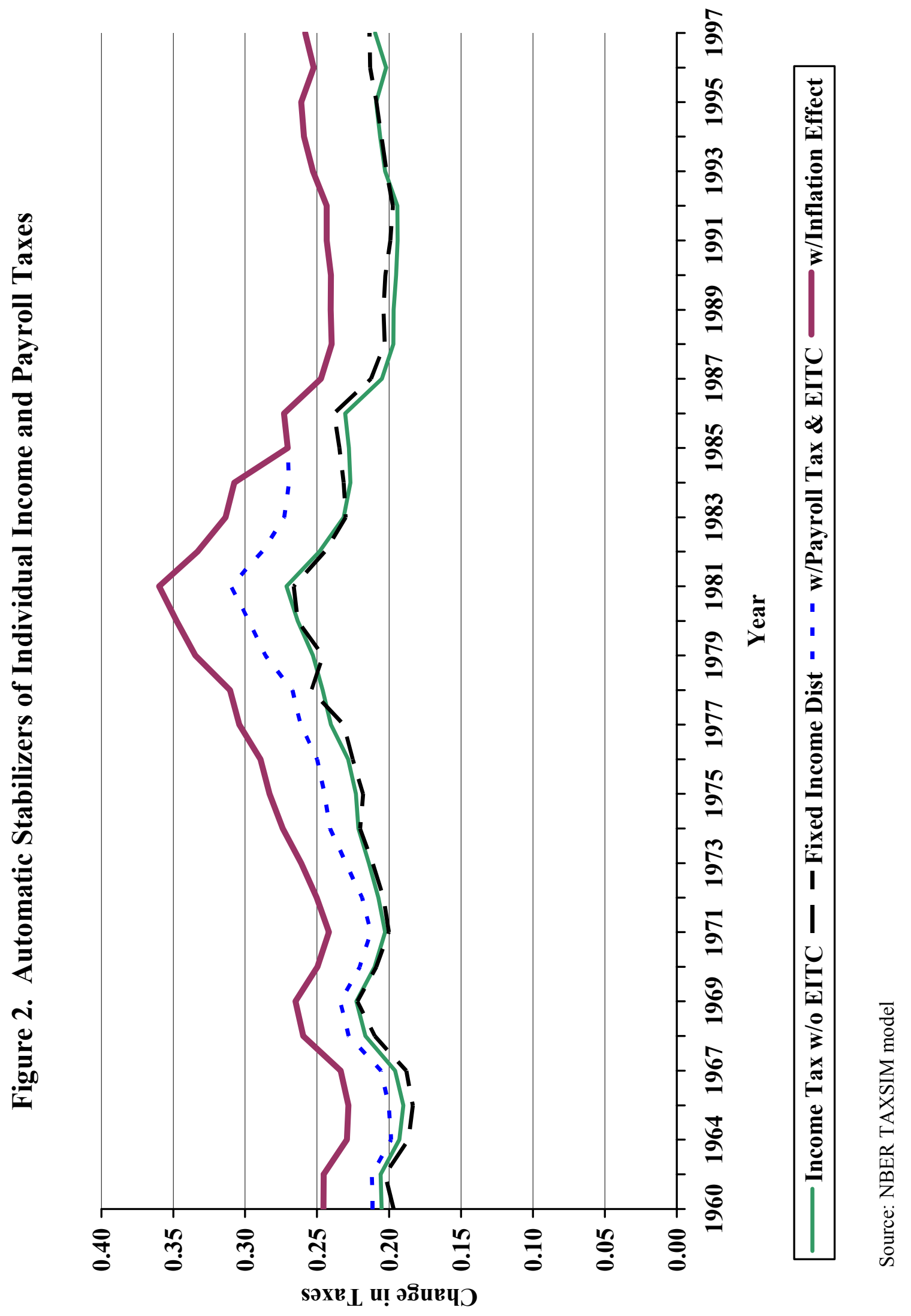




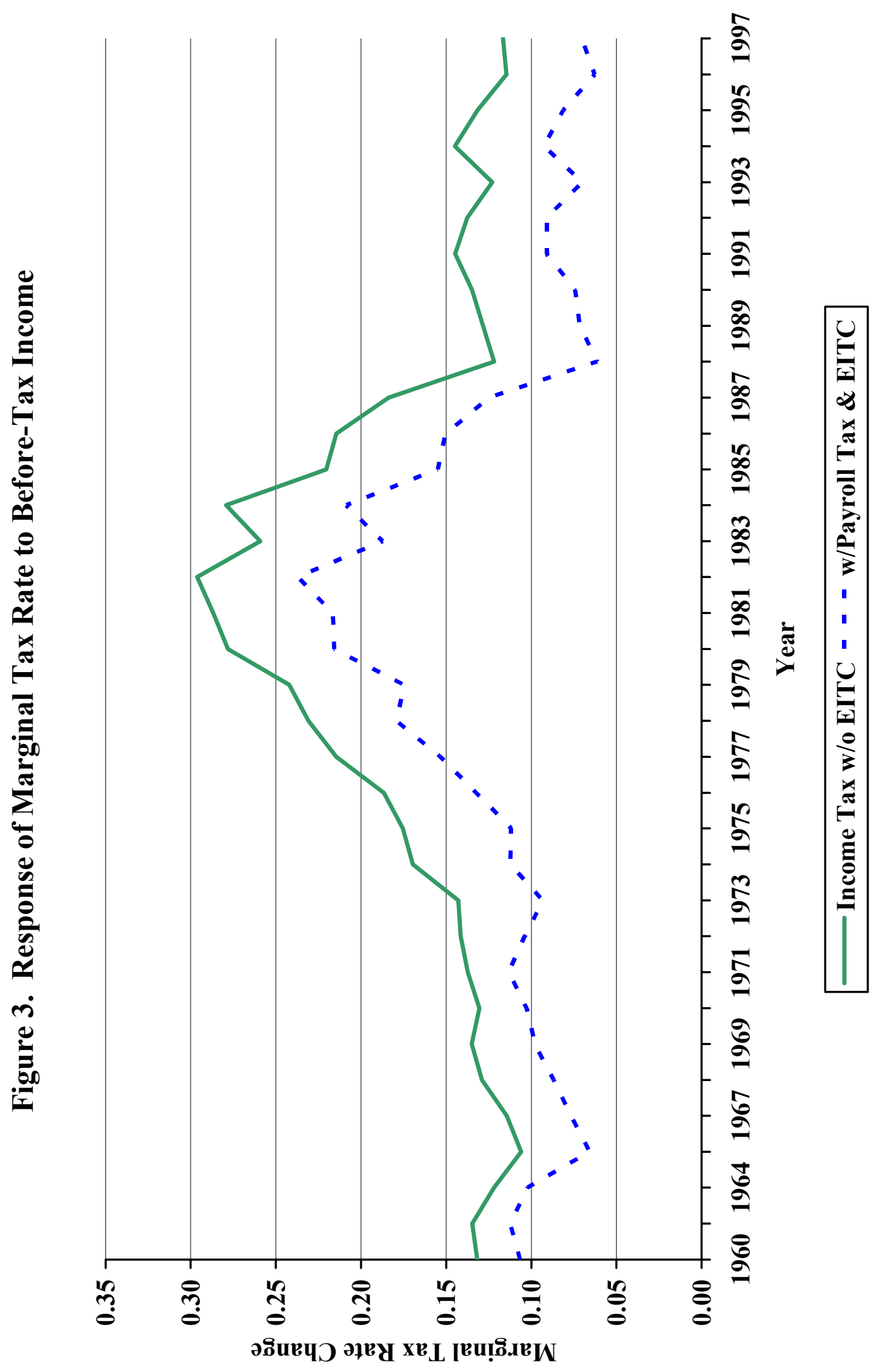

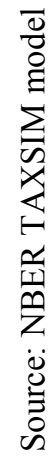




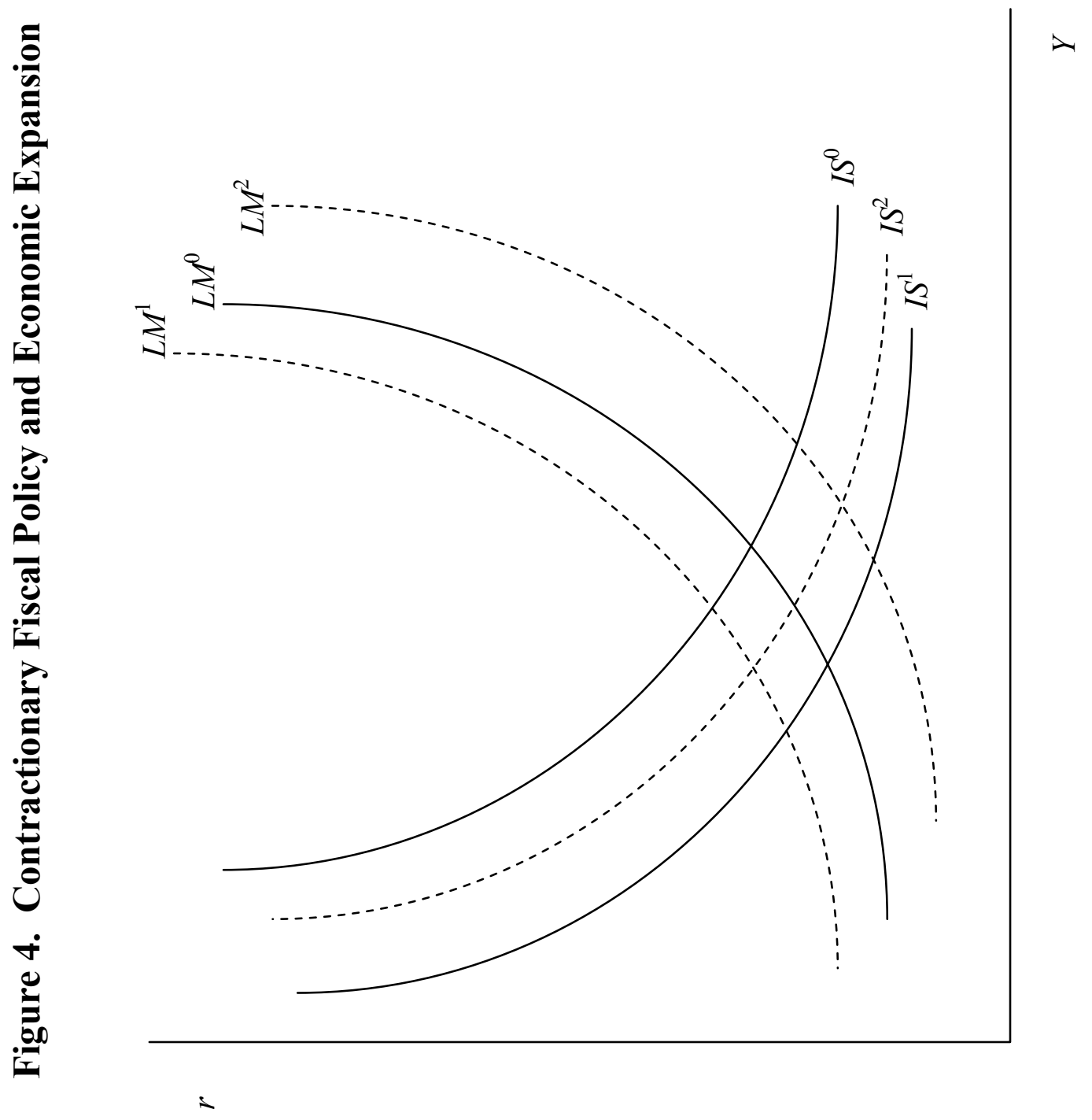




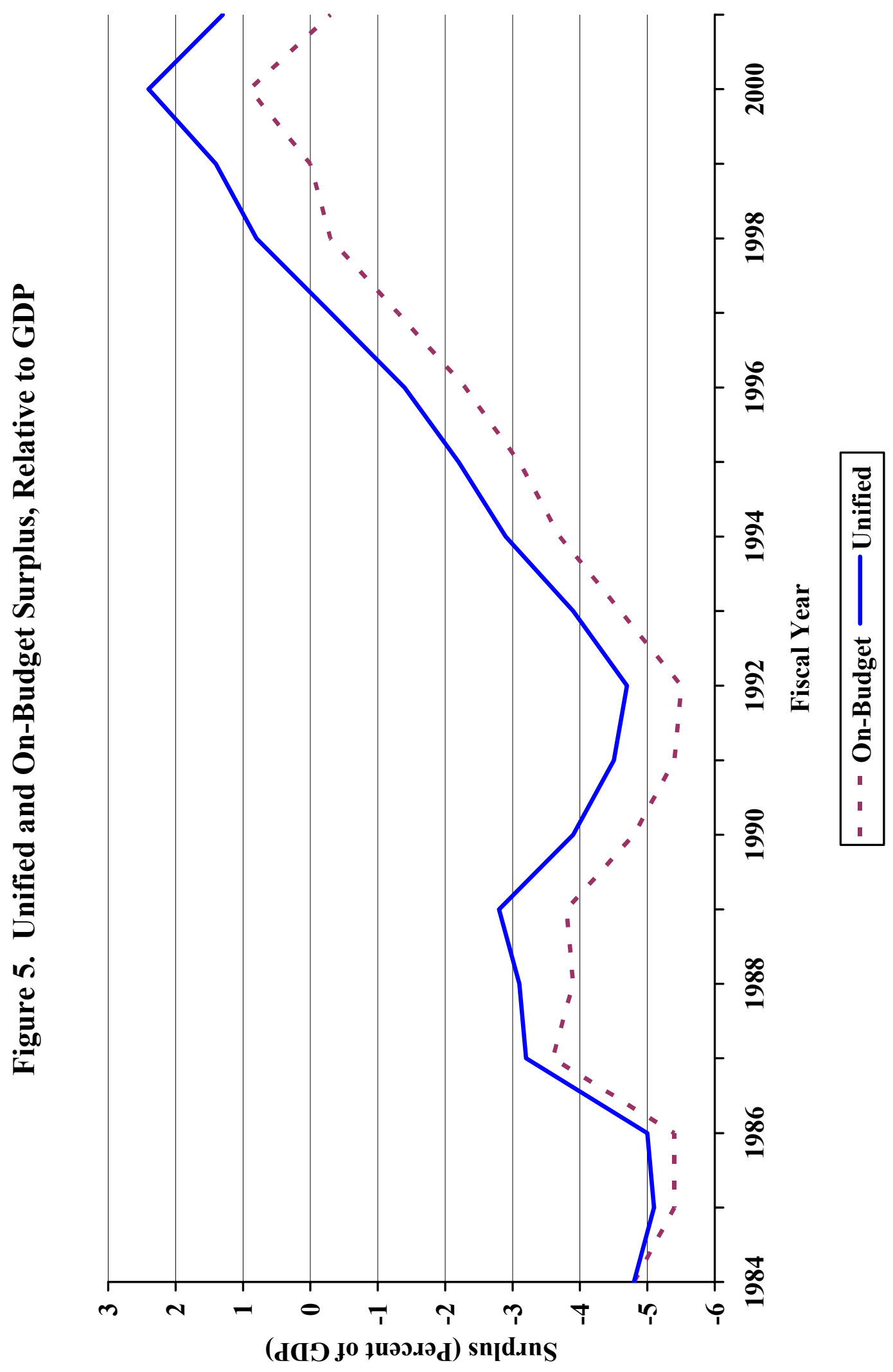

0
0
0
0
0
0
0
0
$\overline{0}$
0
0
0
0
0
0
0
0
0
0
0
0
0 